\title{
SZIMULÁCIÓS ELJÁRÁSSAL TÁMOGATOTT 3D NYOMTATÁS
}

\author{
Balogh Bence \\ hallgató, Miskolci Egyetem, Anyagszerkezettani és Anyagtechnológiai Intézet \\ 3515 Miskolc, Miskolc-Egyetemváros, e-mail: balogh.bence.cc@mail.com \\ Kovács Péter Zoltán \\ egyetemi docens, Miskolci Egyetem, Anyagszerkezettani és Anyagtechnológiai Intézet \\ 3515 Miskolc, Miskolc-Egyetemváros, e-mail: metkpz@uni-miskolc.hu

\section{Szávai Szabolcs} \\ egyetemi docens, Miskolci Egyetem, Gép- és Terméktervezési Intézet \\ 3515 Miskolc, Miskolc-Egyetemváros, e-mail: szavai.szabolcs@uni-miskolc.hu
}

\begin{abstract}
Absztrakt
A negyedik ipari forradalom rengeteg új technológiának adott lenditö eröt, hogy kinöje magát általánosan használt ipari alkalmazássá, illetve, hogy általános társadalmi felhasználási rétegekben is megjelenjen. Az ilyen technológiák egyike az additiv gyártástechnológia, melynek során térbeli tárgyakat készítenek újabb és újabb rétegek hozzáadásával. A cikkben az additív eljárás, mint gyártási technológia kerül elemzésre anyagszerkezeti szempontból. A tanulmány keretében hangsúlyt fektetünk a polimerekböl létrehozott próbatestek különbözö nyomtatási paramétereire. Kutatásunk célja a nyomtatott darabok vetemedésének, zsugorodásának szoftveres vizsgálata, az eredmények összehasonlitása, továbbá a nyomtatási paraméterek hatásának vizsgálata a termék jellemzőire.
\end{abstract}

Kulcsszavak: additív gyártás, gyártástechnológia, polimer, FDM, nyomtatási hiba

\section{Abstract}

The Fourth Industrial Revolution has given impetus to a wealth of new technologies to grow into a commonly used industrial application, and to reach out to the general public. One of these technologies is additive manufacturing technology, in which spatial objects are created by adding new layers. In this article, the additive process as a production technology is analyzed from the point of view of material structure. In the course of this study, we will emphasize the various print parameters of polymer specimens. The aim of our research is to study the warping and shrinkage of printed parts by software, to compare the results, and to examine the effect of printing parameters on product characteristics.

Keywords: additive manufacturing, manufacturing, polyme, FDM, printing anomalies

\section{Bevezetés}

A müszaki iparban a 3D nyomtatás egyik leggyakoribb alkalmazási területe a prototípus-készítés. Vizualizációs vagy kommunikációs modellek segítségével, lényegesen egyszerübb bonyolult terméket is bemutatni. Ellenőrizni lehet vele a szerelhetőséget, nyomtatott alkatrészek esetén megfigyelhetők az esetleges illesztési hibák, illetve a szerelhetőség korlátossága is. A technológia egyre inkább teret hódít a szerszámkészítésnél és az öntészetben is. Alkalmas továbbá kisszámú sorozatgyártásra. Kedvező tu- 
lajdonságainak köszönhetően használják az elektronikai, illetve az üriparban is [1-4]. Azonban az additív gyártás eddig sok esetben tapasztalati úton müködött és a hibafeltárások és azok javítása egy elkészült nyomtatvány alapján került meghatározásra. Fröccsöntésre létezik több szimulációs és VEM program, ami elősegíti a sikeres gyártási eljárást ezzel spórolva a projektköltségeken. Ebben a cikkben szeretnénk feltárni, hogy milyen szimulációs lehetőség áll fent a nyomtatási hibák megelőzésére és hogyan használhatjuk fel öket.

\section{Additív gyártástechnológia típusok}

A 3D nyomtatási technológiák a használt anyag és annak felhasználása szerint különböző csoportokra oszthatók. A technológiák csoportosítását az 1. ábra szemlélteti. Mivel a cikk célja polimer anyagú nyomtatott próbatestek vizsgálata, jelen fejezetben az ilyen típusú anyagot használó 3D nyomtatók kerülnek bemutatásra. Az 1. ábrán láthatunk egy átfogó képet a nyomtatási technológiákról. A cikkben végzett kutatáshoz FDM (Fused Deposition Modeling, ami magyarul a szálhúzásos 3D nyomtatásnak felel meg) típusú nyomtatóval készültek az elemzésre kerülő minták és próbadarabok. Emellett említés szintjén a további technológiák is polimer anyaggal dolgoznak, de más elvi módon müködnek. Az SLA (Stereolithography $=$ Sztereolitográfia $)$ és a DLP $($ Digital Light Processing $=$ Digitális fényfeldolgozás $)$ folyékony fényre érzékeny polimereket alkalmaz és lézer vagy LED fényforrás segítségével hozza létre a modell egyes szegmenseit, amíg az teljesen fel nem épül. Az SLS (Selective Laser Sintering = Szelektív lézer szinterezés) föleg nejlon és poliamid porból, lézer segítségével dolgozik. Az MJ (Material Jetting = „Anyag sugárzás”) a hagyományos 2D nyomtatók felépítéséhez hasonlít, ahol egy mozgó fej folyékony fényre érzékeny anyagot terít a munkaasztalra és fényforrás segítségével megszilárdítja azt. A BJ (Binder Jetting = „kötőanyag-sugárzás”) 3D nyomtatás lényege, hogy a 3D nyomtató finom porrétegeket fektet le, s ezekre rajzolja meg festékkel kevert ragasztóanyaggal a nyomtatandó tárgy rétegeit. A DMLS és SLM (Direct Metal Laser Sintering, Selective Laser Melting = Direkt fém lézer szinterezés, Szelektív lézeres olvasztás) nem elhanyagolandó, azonban a fém 3D nyomtatás egy olyan másik mély témakör, amit jelen cikk során nem tárgyalunk.

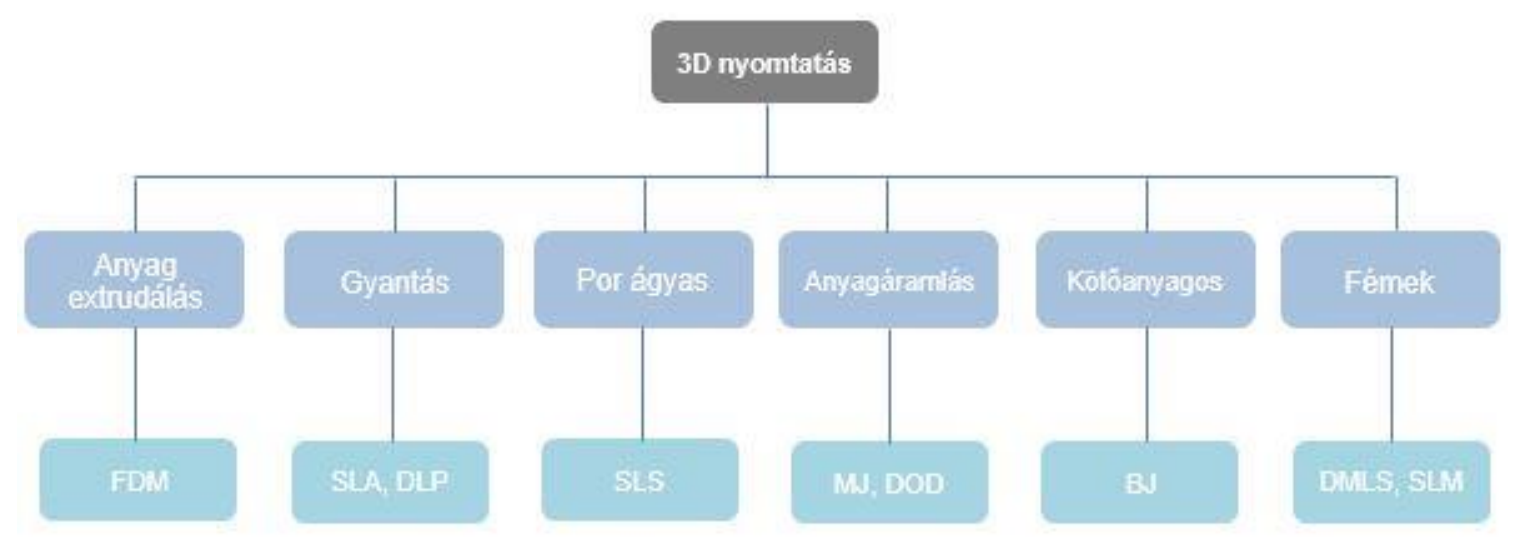

1. ábra. 3D nyomtatók csoportositása 


\section{Anyagextrudálás}

Az FDM nyomtatók müködése egyszerü, egy tekercs nyomtatószál felhelyezése és befüzése után, a nyomtató léptető motorok segítségével extrudálja azt egy felfütött fúvókán, ahogy a 2. ábrán is látható. A nyomtató az általunk generált pálya mentén mozgatja a fejet, ami olvadt anyagot fektet a tárgyasztalra, ahol az anyag lehül és kikeményedik. Amint elkészült egy réteg a nyomtató egy újabbat készít addig, amíg a teljes modell felépül. A legáltalánosabban használt rétegvastagság $0,2 \mathrm{~mm}$. A FDM technológiával készült nyers darabokon, néhány esetben, például nagyobb rétegvastagság alkalmazása esetén látszódhatnak a rétegek. Ezek csiszolással, polírozással kezelhetők. Az elérhető méretpontosság $+/-0,5 \%$. A nyomtatási időt jelentős mértékben befolyásolja a kiválasztott modell mérete, bonyolultsága és felületminősége. Legfőbb előnye, hogy nincs szükség kémiai utókezelésekre, a gép és a felhasznált anyagok viszonylag olcsók.

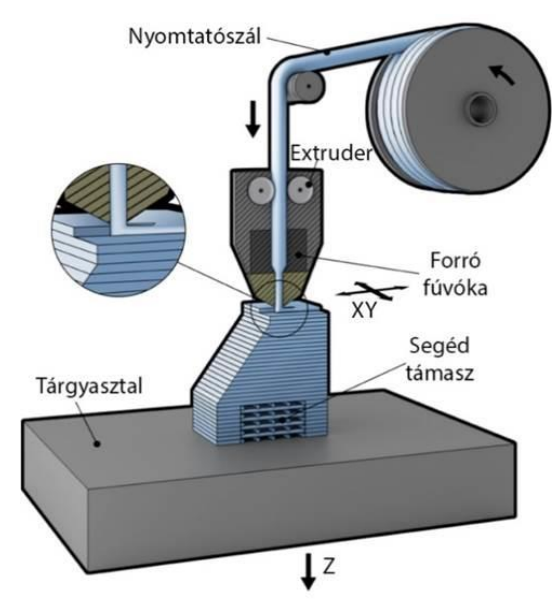

2. ábra. Szálhúzásos technológia müködési elve [15]

\section{PLA és ABS összehasonlítása}

A PLA egy népszerű könnyen kezelhető anyag, az ABS pedig széles körben használt polimer, nem csak a 3D nyomtatásban. Továbbá ez a két anyag olcsón beszerezhető és a szoftverek adatbázisában is többnyire elérhető, ezért ebben a fejezetben ezek az anyagok kerülnek elemzésre.

\subsection{PLA}

A politejsav, röviden PLA (Polylactic Acid = Politejsav) a legnépszerübb biopolimerként, a biodegradábilis polimerek rendkívül fontos képviselője. Kémiailag $\left(\mathrm{C}_{3} \mathrm{H}_{4} \mathrm{O}_{2}\right)_{\mathrm{n}}$ szerkezeti felépítéssel rendelkezik, ami a 3. ábrán látható. A sürüsége 1,210-1,430 $\mathrm{g} \cdot \mathrm{cm}^{-3}$ között változhat a gyártási eljárás és a színezékek és egyéb keverési anyagok függvényében. A PLA vízben nem oldódik, az olvadáspontja $\sim 20{ }^{\circ} \mathrm{C}$, nyomtatásra azonban $190-210^{\circ} \mathrm{C}$ az ideális. 


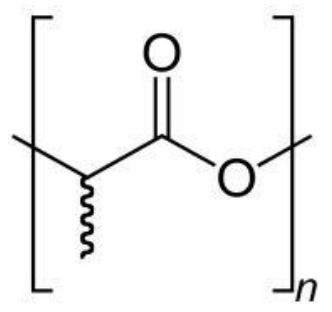

3. ábra. A politejsav szerkezeti képlete [16]

Biológiai alapú anyagokból, például búzából, kukoricából és cukorrépából kivont keményítőből vagy cukorból állítják elő. Lebomlásakor víz, humusz és szén-dioxid keletkezik, így nem szennyezi a környezetet. A lebomlás komposztban $\left(\mathrm{T}>60^{\circ} \mathrm{C}\right)$ néhány hónap alatt végbemegy, biotikus környezetben nem bomlik. Mivel a bomlása csak a kezdeti hidrolízis után indul meg, szobahőmérséklet mellett szinte teljesen stabil, a belőle készített termék hosszútávon, évekig használható marad [5], [6].

A PLA a legnépszerübb anyag az FDM típusú 3D nyomtatás esetén. Olcsó, sokféle színben, árnyalatban és stílusban érhető el, így széles körben használható a különböző alkalmazásokban. Könnyen nyomtatható, alacsonyabb olvadásponttal rendelkezik, mint a többi nyomtatószál anyag, így a nyomtatásához alacsonyabb hőmérsékletre van szükség. Az egyik legfontosabb előnye az, hogy nem mérgezö, nyomtatása során nem keletkezik intenzív, rossz szagú gőz. A PLA vetemedése, illetve zsugorodása kicsi, így a nyomtatása során nem kötelezö fütött asztal használata, azonban ajánlott.

Mivel a PLA merev nem ajánlott az alkalmazása hajlékony, kopásálló tárgyak esetén, továbbá $60^{\circ} \mathrm{C}$ vagy annál magasabb hőmérsékleten deformálódik, ebből adódóan nem ajánlott a használata olyan alkalmazásokban sem, ahol kritérium a magas hőmérsékletállóság [7], [8].

\subsection{ABS}

Az akrilnitril-butadién-sztirol (ABS) egy olyan amorf polimer, amely akrilnitril és sztirol emulziós, vagy tömb polimerizációjával készül polibutadién jelenlétében, a kémiai szerkezeti képlete $\left(\mathrm{C}_{8} \mathrm{H}_{8} \cdot \mathrm{C}_{4} \mathrm{H}_{6} \cdot \mathrm{C}_{3} \mathrm{H}_{3} \mathrm{~N}\right)_{\mathrm{n}}$, amit a 4 . ábra szemléltet.

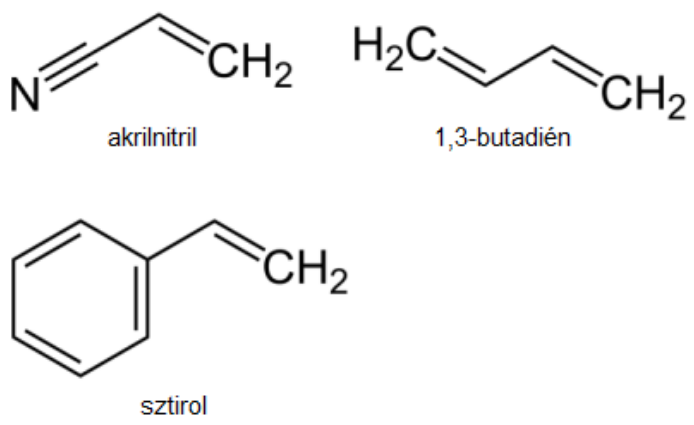

4. ábra. ABS monomerek szerkezeti képletei [16]

A sztirol monomer biztosítja az ABS jó feldolgozhatóságát, az antikril adja a keménységet, a kémiai ellenállóságot, illetve a hőállóságot, a butadiéntől pedig a termék alacsonyabb hőmérsékleten is keményebb és rugalmasabb lesz. Különböző, specifikus tulajdonságokkal rendelkező minőségeket eredményez az összetevők arányának módosítása, illetve a speciális adalékanyagok használata. 
Az ABS hosszú történelemmel rendelkezik a 3D nyomtatás világában, mivel az első olyan polimerek közé tartozik, amelyeket ipari nyomtatás során használtak. Napjainkban az ABS a PLA után a második legnépszerübb nyomtatószálanyag, köszönhetően az alacsony árának és a jó mechanikai tulajdonságainak, keménységének, ütésállóságának és tartósságának. Alkalmas tartós, kopásálló alkatrészek nyomtatására. Olvadáspontja magasabb a nyomtatószálak anyagaihoz képest, ebből adódóan használatakor magas nyomtatási hőmérséklet biztosítása szükséges, ami $220-250^{\circ} \mathrm{C}$ között alakul. ABS használata esetén fontos az asztal fütése $90-110^{\circ} \mathrm{C}$-ra és a megfelelö hőmérsékletszabályozás. Hátrányai közé tartozik a vetemedésre való hajlamossága, illetve a körülményes nyomtatása, hiszen magasabb hőmérsékleteket kell alkalmazni, nem zárt nyomtató esetén fokozott figyelmet kell fordítani a vetemedés elkerülésére, illetve karima alkalmazásával utómunkára van szükség. Nyomtatásakor intenzív gőz szabadul fel, ezért használata jól szellőző környezetben ajánlott [7], [9].

\section{Leggyakoribb nyomtatási hibák}

A 3D nyomtató legyen az ipari vagy hobbi szintü gép egy komplex berendezés, ami folyamatos odafigyelést és karbantartást igényel. Amennyiben ritkán foglalkozunk a gépünk állapotával, akkor különböző problémák merülhetnek fel a nyomtatás során, amiből párat megtekinthetünk az 5 . ábrán. A következőkben bemutatásra kerülnek a legjelentősebb hibák, a vetemedés és a zsugorodás.

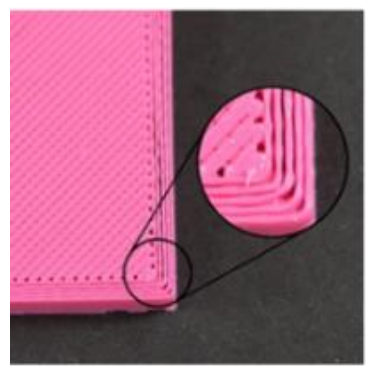

Alul extrudálás

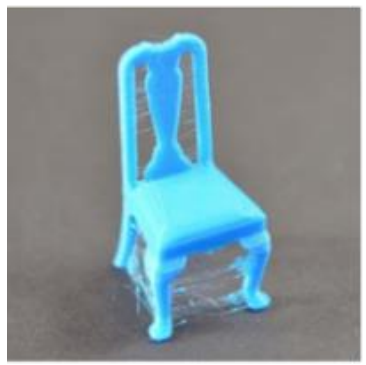

„Pókhálózás”

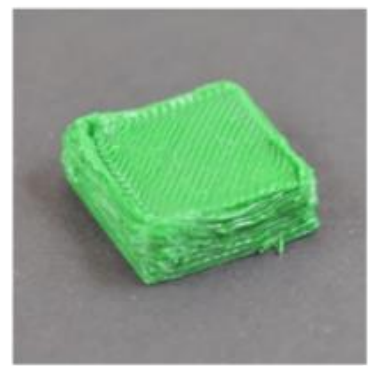

Felül extrudálás

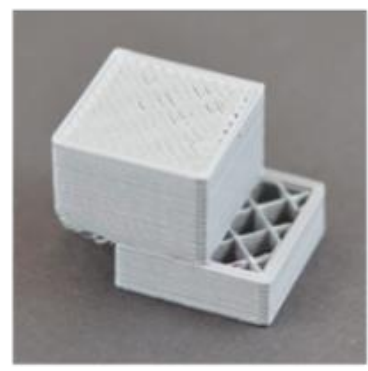

Rétegelmozdulás

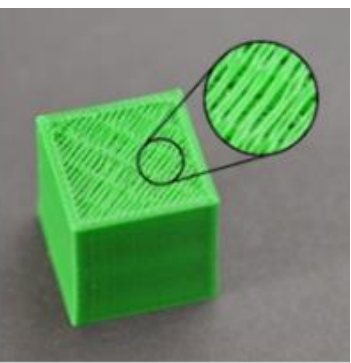

Felső réteg hiba

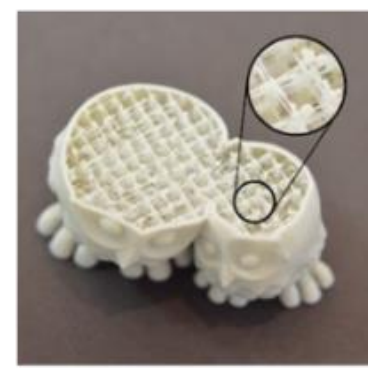

Gyengekitöltés

\section{5. ábra. Gyakori nyomtatási hibák [17]}

Az egyik leggyakoribb probléma nyomtatott alkatrészek körében a vetemedés. Fontos a vetemedés és a zsugorodás fogalmak megkülönböztetése. A zsugorodás jelentése az, hogy a munkadarab minden mérete a lehülés következtében azonos mértékben csökken, ehhez viszont ideális esetben végtelen időre lenne szükség. A valóságban a zsugorodás együtt jár bizonyos mértékü belső feszültség növekedéssel. Ennek mértéke a polimereknél akár a 10-15\%-ot is meghaladhatja. Vetemedés közben a termék méretei 
nem azonos mértékben változnak meg, hanem a nagyobb keresztmetszetekben nagyobb mértékủ zsugorodás van jelen, amely vetemedéshez vezet. Vagyis a vetemedés a zsugorodásból származik, de nem azonos azzal.

Minél nagyobb modelleket nyomtatunk annál nagyobb vetemedés észlelhető. Az első rétegek megfelelő letapadása esetén is idővel megfigyelhető, hogy elkezdenek felkunkorodni a sarkak, vagy egyéb helyeken deformálódik a modell. A kunkorodás, akár a modell felválását is okozhatja, ami a teljes nyomtatás hibára futását eredményezi. A vetemedés akkor jelentős, ha nagyméretủ és hosszú darabokat készítünk magas olvadáspontú anyagokkal, mint a korábban említett ABS. Például egy $230{ }^{\circ} \mathrm{C}$-on nyomtatott $\mathrm{ABS}$ szobahőmérsékletre hülése során akár 1,5\%-ot is deformálódhat. Igazán nagy modellekénél ez milliméteres eltéréseket is jelenthet [10], [11]. A 6. ábra egy 3D nyomtatott darab vetemedését mutatja be.

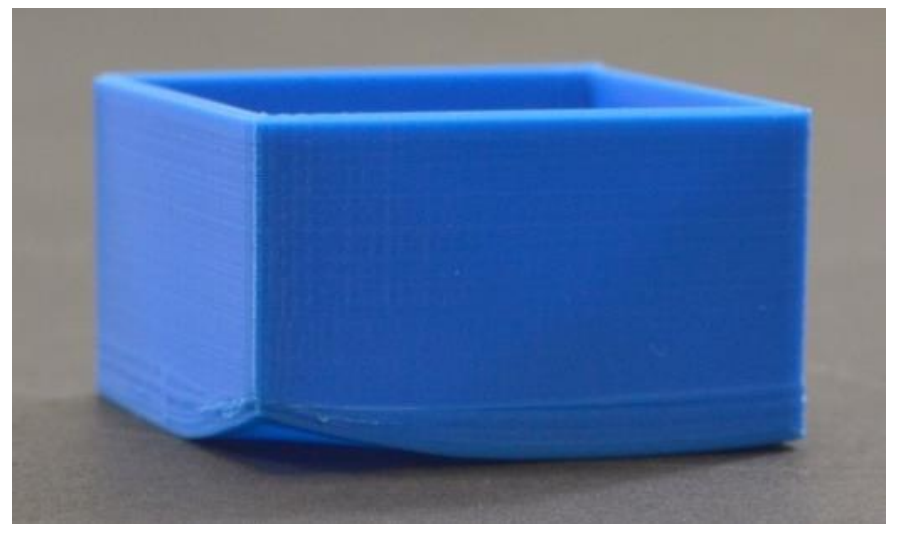

6. ábra. Vetemedés [10]

A vetemedés kiküszöbölésére, illetve mértékének csökkentésére különböző módszerek ismertek. Az egyik módszer fütött tárgyasztal és zárt nyomtatóház használata, az egyenletes hőmérséklettartás érdekében. További megoldás a nyomtatás során, a darab köré karimát (Brim) készíteni (7. ábra). A karima a modell alsó síkjaihoz hozzákötött körvonal. A karimát megnövelt körvonalszámmal szokták alkalmazni, ezzel egy gyürüt létrehozva az alkatrész körül. Ennek használatával megelőzhető a nyomtatott darab alsó síkjának felválása és vetemedése [12].

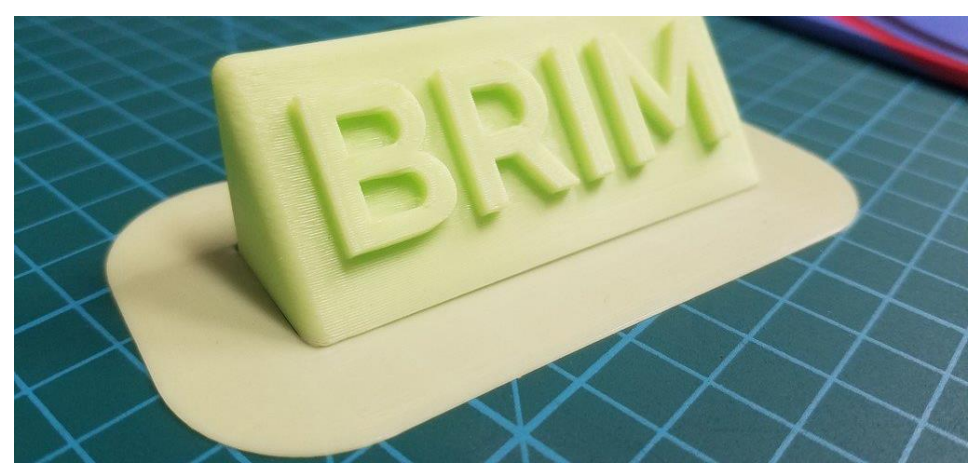

7. ábra. A vetemedés és a nem megfelelö letapadás elkerülés érdekében alkalmazott karima [17] 


\section{Nyomtatási hőmérsékletek meghatározása}

A kutatásaink során készített próbatestek anyagául a HobbyKing által forgalmazott, $1,75 \mathrm{~mm}$ átmérỏjü PLA és ABS anyagokat választottuk. A gyártók minden anyaghoz megadnak egy ajánlott nyomtatási hőmérsékletet, ami az általunk használt, $200{ }^{\circ} \mathrm{C}$ olvadáspontú PLA esetében $210-235^{\circ} \mathrm{C}$, a $\sim 230{ }^{\circ} \mathrm{C}$ olvadáspontú ABS esetében $230-260^{\circ} \mathrm{C}$. Ahhoz, hogy megállapítsuk pontosan a megfelelő nyomtatási hőmérsékleteket, ún. hőmérséklettornyokat nyomtattunk mindkét anyag esetében (8. ábra).

A hőmérséklettornyok nyomtatásának előtervezése során különböző hőmérsékleti sávokat hoztunk létre, minden sávnak azt a hőmérséklet értéket állítottuk be, ami a modell azon részén szerepel.

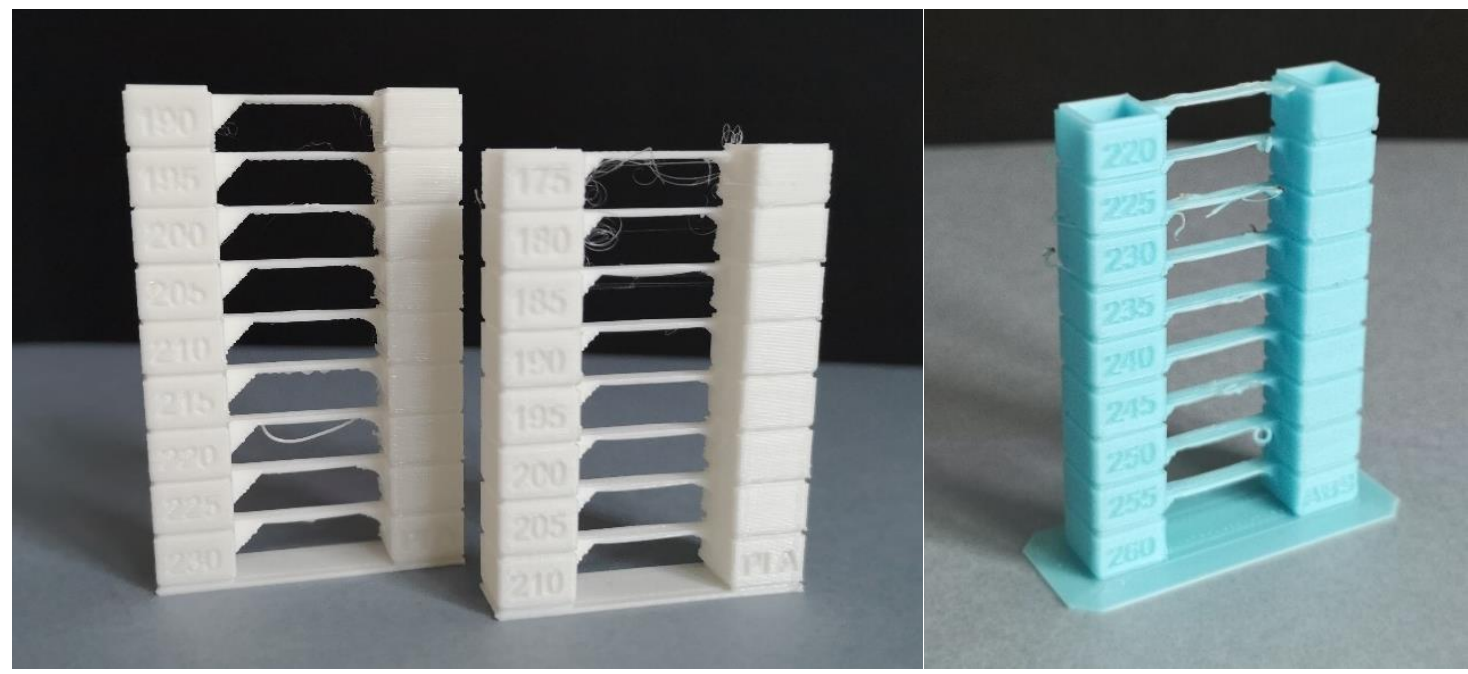

\section{8. ábra. Hömérséklettornyok}

A sávok nyomtatása során a nyomtatási hőmérséklet minden váltásnál $5^{\circ} \mathrm{C}$-ot csökken. PLA esetében 230-170 ${ }^{\circ} \mathrm{C}$-ig, míg ABS esetében $260-220^{\circ} \mathrm{C}$-ig vizsgáltuk az anyagokat. A túlságosan magas nyomtatási hőmérsékletek használatakor, PLA anyagnál $230-215^{\circ} \mathrm{C}$-ig, ABS anyagnál $260-245^{\circ} \mathrm{C}$-ig az anyag túlságosan megfolyt, ezzel nyomtatási hibákat hozott létre. A hőmérséklet csökkentésekor, egy bizonyos érték után, PLA esetén $185^{\circ} \mathrm{C}$-tól, ABS esetén $235^{\circ} \mathrm{C}$-tól, megjelent az úgynevezett pókhálózás effektus, a rétegek nem tapadtak kellően össze, csökkentve ezzel mind az esztétikai, mind a mechanikai tulajdonságokat. PLA használatakor a $170{ }^{\circ} \mathrm{C}$ hőmérsékletű sáv megkezdésekor a rétegek közti adhézió annyira kicsi volt, hogy azok nem tapadtak az előző réteghez, így a nyomtató ezt a sávot már nem tudta elkészíteni.

A hőmérséklettornyok és az előző tapasztalataink alapján PLA esetében a $210^{\circ} \mathrm{C}$-ot, ABS esetében pedig a $240^{\circ} \mathrm{C}$-ot választottuk a nyomtatás hőmérsékleteként.

\section{ABS vetemedés modellezése}

A Digimat-AM a Digimat szoftvercsomag legújabb, 2017-ben kiadott modulja, egy folyamatszimulációs szoftver, amely polimerek és kompozit anyagok additív gyártásának szimulálására szolgál $[9,18$, 19]. Lehetővé teszi a mérnökök számára a nyomtatott darab vetemedésének, a hőmérsékletviszonyoknak és a maradó feszültségeknek a vizsgálatát a nyomtatási paraméterek és az anyagválasztás függvényében. A Digimat AM szimulációk segítségével a nyomtatási beállítások optimalizálhatók, még a fizikai nyomtatás előtt, például a megfelelő vetemedéskompenzáció azonosításával. A szoftver egyszerü és hatékony 
munkafolyamatot biztosít, a nyomtatási projekt definiálásától kezdve, a különbözö gyártási paraméterek beállításával, a szimuláció beállításával és az eredmények kiértékelésével (9. ábra). Az irodalmak feldolgozása és a tapasztalat is azt mutatta, hogy PLA esetében elhanyagolható a vetemedés, viszont ABS felhasználásánál komoly probléma. A szimulációs szoftver csak egy bizonyos időablakban állt rendelkezésünkre, így kizárólag az ABS-re fókuszáltunk.

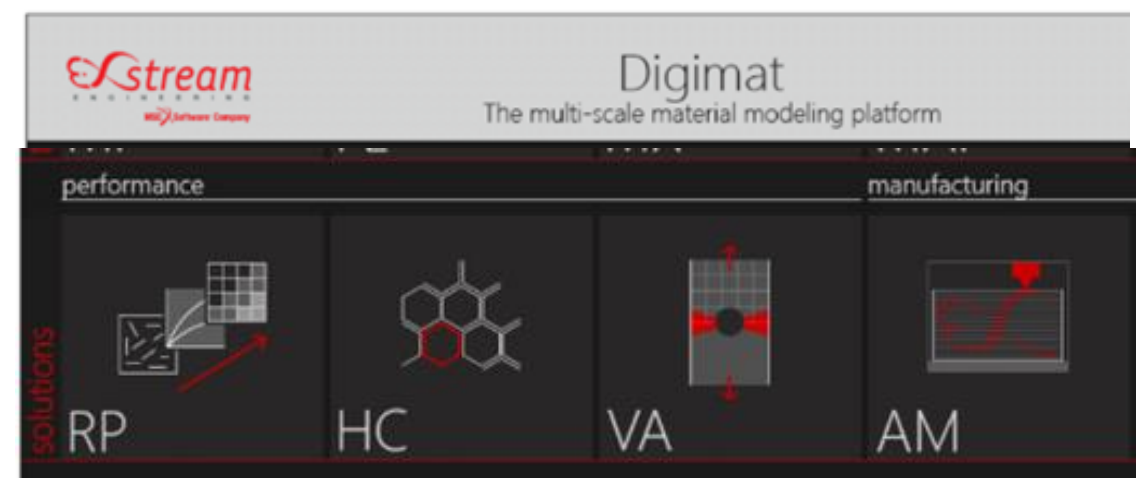

9. ábra. Digimat AM szoftvercsomag moduljai [14]

A Digimat-AM egy négylépcsős irányított munkafolyamatot vezet be a polimerek és a kompozitok additív gyártási folyamatának előrejelzésére és optimalizálására.

- Meghatározás: Első lépésként kiválasztható a nyomtatási eljárás, a nyomtató és meghatározható a gyártandó alkatrész leírása. Ez utóbbit a darab geometriája és annak anyaga határozza meg.

- Gyártás: Ez a lépés lehetővé teszi az alkatrész gyártásának leírását. Itt különféle paraméterek megadására van lehetőség, mint például a pozicionálás, FFF és FDM típusú nyomtatás esetén a nyomtatófej útvonala, a gyártási lépések sorrendje és egyéb, a gyártás típusától függő folyamatparaméterek. Ennek a résznek a végére, az alkatrész gyártása teljes mértékben definiálásra kerül, és készen áll a szimulációra.

- Szimuláció: Ez a harmadik lépés, amely lefordítja a meghatározást és a gyártást egy tényleges végeselem szimuláció során. Itt elkészíthető a geometria hálója, illetve különböző megoldási módszerek választhatók. A szimulációs modell elkészítése után, a szimuláció futtatható és nyomon követhetö a befejezésig.

- Eredmények: Ez a lépés biztosítja a szimulációs eredmények feldolgozásához szükséges funkciókat, például az elmozdulás és a feszültség térbeli vizualizációját, a vetemedés elemzését, a vetemedett alak ábrázolását, illetve a szimuláció eredményeinek az exportálását [14].

\section{A próbadarab geometriája}

3D nyomtatás során, az ABS nyomtatószál használatával készített darabok nagy hajlamosságot mutatnak a vetemedésre, azonban PLA esetében ez elhanyagolható mértékü.

A Digimat-AM moduljának próbaverziójával vizsgáltuk az ABS anyag vetemedését, illetve a darabban keletkező maradó feszültségeket. A $40 \times 40 \times 40 \mathrm{~mm}$ befoglaló méretű próbadarabot Solid Edge ST10 tervezőprogram segítségével készítettük el, melynek geometriáját a 11. ábra mutatja be. 


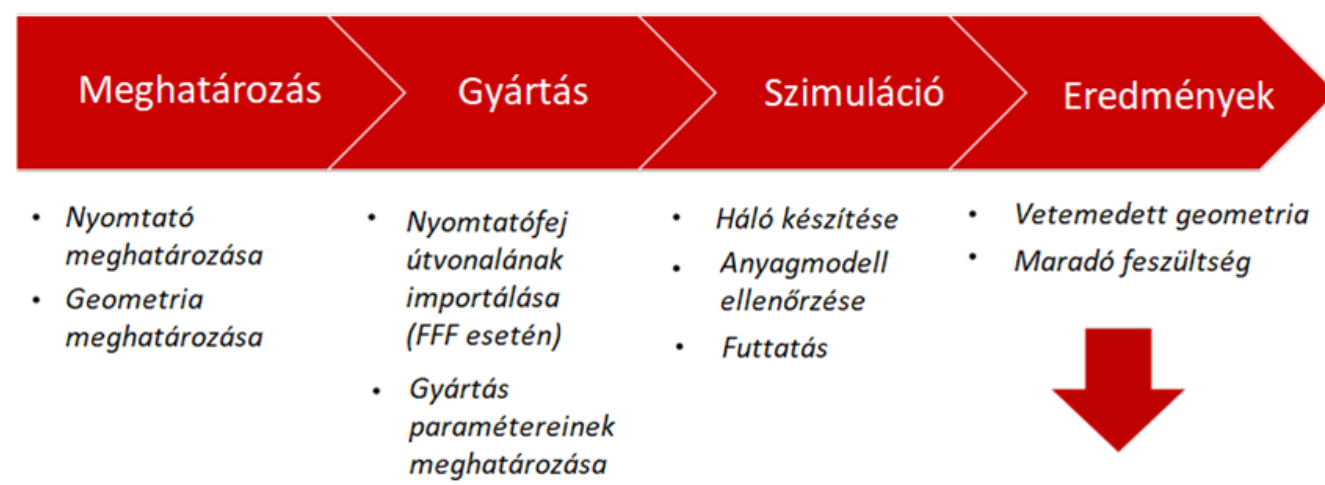

Eredmények kiértékelése

10. ábra. Digimat-AM szimuláció föbb lépései [14]

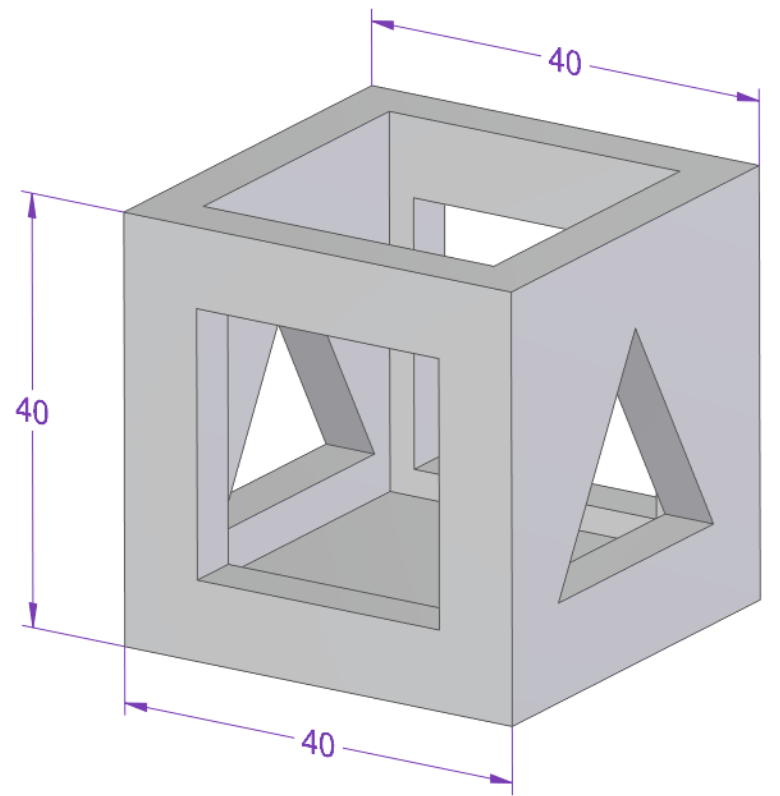

11. ábra. A próbadarab geometriája

\section{Digimat-AM szimuláció}

A szimuláció felépítésének első lépése az alapvető paraméterek meghatározása, ahol a nyomtatót lehet definiálni. Miután elneveztük a projektünket, kiválasztjuk a nyomtatási eljárás típusát, ami lehet SLS, FFF és FDM. Jelen esetben az FFF-et választjuk és mivel a nyomtatónk nincs benne a Digimat elöre meghatározott listájában, ezért megadjuk a munkaterület paramétereit, ami esetünkben $230 \times 230 \mathrm{~mm}$ az X és Y tengelyen, valamint $250 \mathrm{~mm}$ a Z tengely irányában. Ezt követően kiválaszthatjuk, hogy rögzített vagy mozgó platformmal rendelkezik-e a nyomtatónk. A mi esetünkben használt Creality Ender3 típusú nyomtató rögzített tárgyasztallal rendelkezik, mert az $\mathrm{X}$ tengelyre rögzített fej végzi a vertikális 
és horizontális irányú mozgásokat is az asztal egyedül az Y tengely mentén mozog. Az analízis fajtájaként választhatjuk a „vetemedés belső feszültségek alapján”, „vetemedés tranziens termomechanikai tulajdonságok alapján” vagy „hőmérséklet előzmény” meghatározást.

Mi az általános „,vetemedés belső feszültségek alapján” metódust választottuk, mert kielégítő eredményeket ad és nincs szükség nagy számítási erőforrásokra hozzá. Következö lépésben beolvastuk a modellhez tartozó g-kód útvonalakat tartalmazó „.stl” fájlt. A Digimat-AM moduljába beolvasott fájlt a 12. ábra mutatja be.

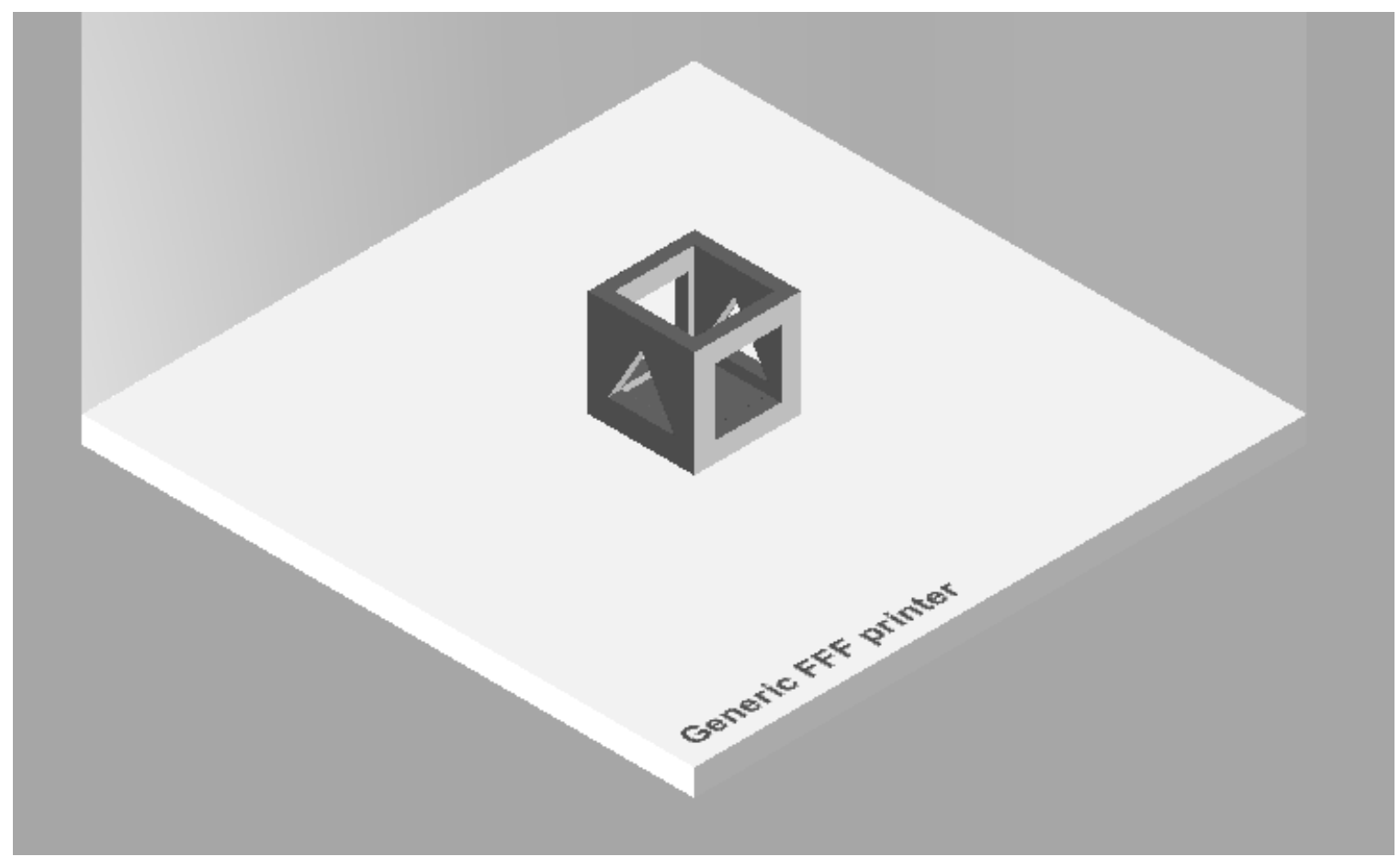

12. ábra. A Digimat-AM moduljába beolvasott geometria

A rendelkezésre álló adatbázisból kiválasztottuk az „FFF: e-Xstream engineering/e-X_GENERIC_ FFF_ABS" típusú általános ABS anyagot. Van lehetőség saját anyag definiálására is, amennyiben rendelkezésre állnak az anyagegyenlet és egyéb paraméterek a használni kívánt polimerhez. Ezt követően a gyártás beállításai következtek. Kiválasztottuk, a gyártási folyamat lépéseinek a sorrendjét, ami „Nyomtatás-Hütés-Támasz eltávolítás”. Feltöltöttük a Digimat-AM számára a modellünk g-kódját, ami tartalmazza a fej mozgásának útvonalát és megadtuk a folyamat paramétereit a nyomtatónkra vonatkoztatva, amik megegyeznek a valóságban használt paraméterekkel. A tárgyasztal $110^{\circ} \mathrm{C}$-os, a fúvóka pedig $240{ }^{\circ} \mathrm{C}$-os hőmérsékleten fog müködni, 0,4 mm-es fúvóka átmérő és $50 \mathrm{~mm} / \mathrm{s}$-os sebesség mellett. A szimuláció beállításai során beállítottuk a hálózás felbontását, ami esetünkben közepes minőségü 1,5 mm-es „,voxel” típusú, amivel 8604 kockára bontotta a szoftver a geometriát. Amennyiben az anyagmodellben bármilyen módosítást szeretnénk végrehajtani vagy teljesen személyre akarjuk szabni a választott anyagot, azt ebben a lépésben tehetjük meg. A 13. ábra a darab hálózását mutatja be. 


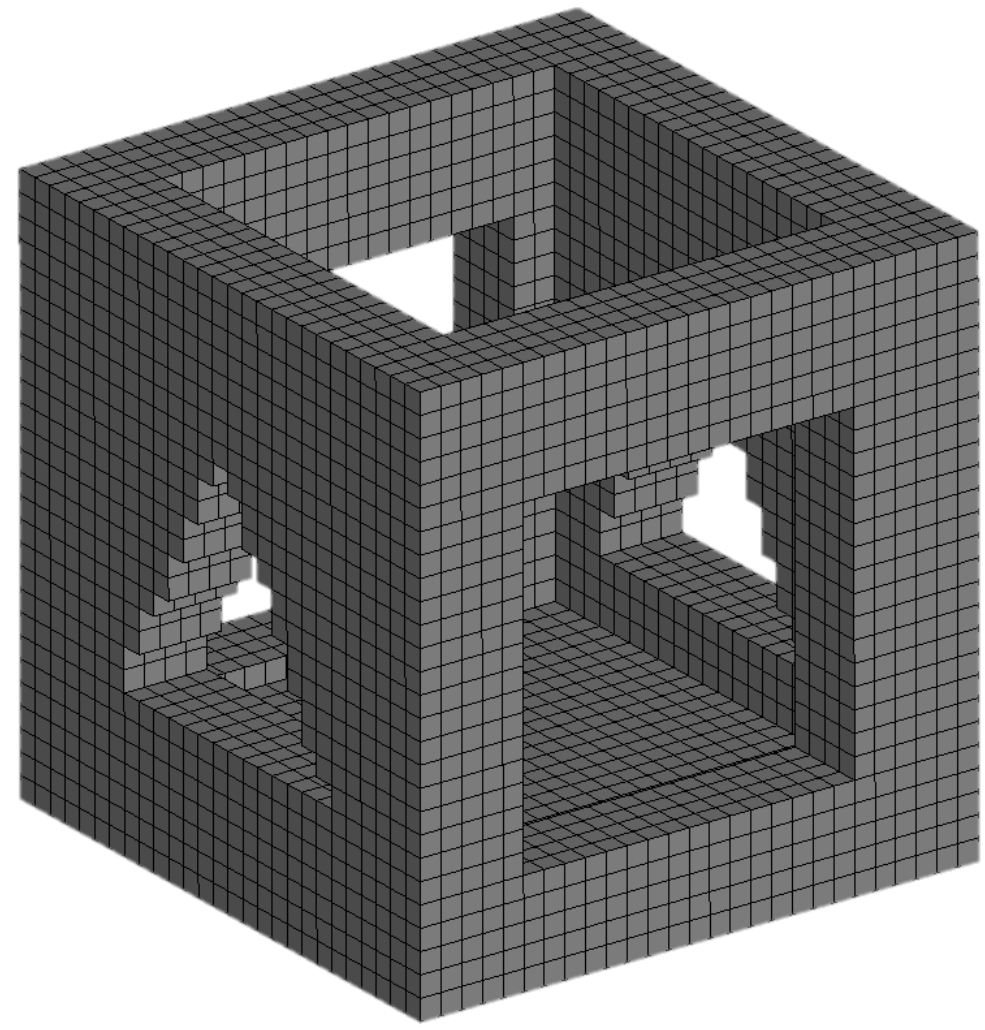

13. ábra. Voxeles háló modell

A szimulációs munkafolyamat elindítása előtt ellenőrizhetjük a bevitt adatokat és a kiválasztott paramétereket. Jóváhagyás után elindíthatjuk a folyamatot.

\section{Eredmények összehasonlítása}

A szimuláció végeztével megtekinthetjük az eredményeket. A vetemedés mértéke mm-es színskála segítségével vizsgálható összesítve vagy külön bontva az XYZ tengelyek valamelyikére. A belső feszültségek hasonló módon, MPa-os színskálán figyelhetők meg a modellen.

A 14. ábra (bal) mutatja a szemléletesség érdekében tízszeres nagyításban a kocka vetemedését. A vetemedés maximális értéke $\sim 0,95 \mathrm{~mm}$ volt. A legnagyobb mértékủ elmozdulás a kocka sarkainál keletkezett. A keletkező feszültségek nagymértékben befolyásolják a vetemedés kialakulását. A jobb oldali ábrarészlet a vetemedés miatt létrejött maradó feszültséget szemlélteti. Látható, hogy a feszültség az éles sarkok mentén mutat csúcsértéket, az oldalsó élek mentén ennek nagysága megközelítőleg 7 MPa. A maradó feszültségek nem jelzik előre a kocka károsodását. 

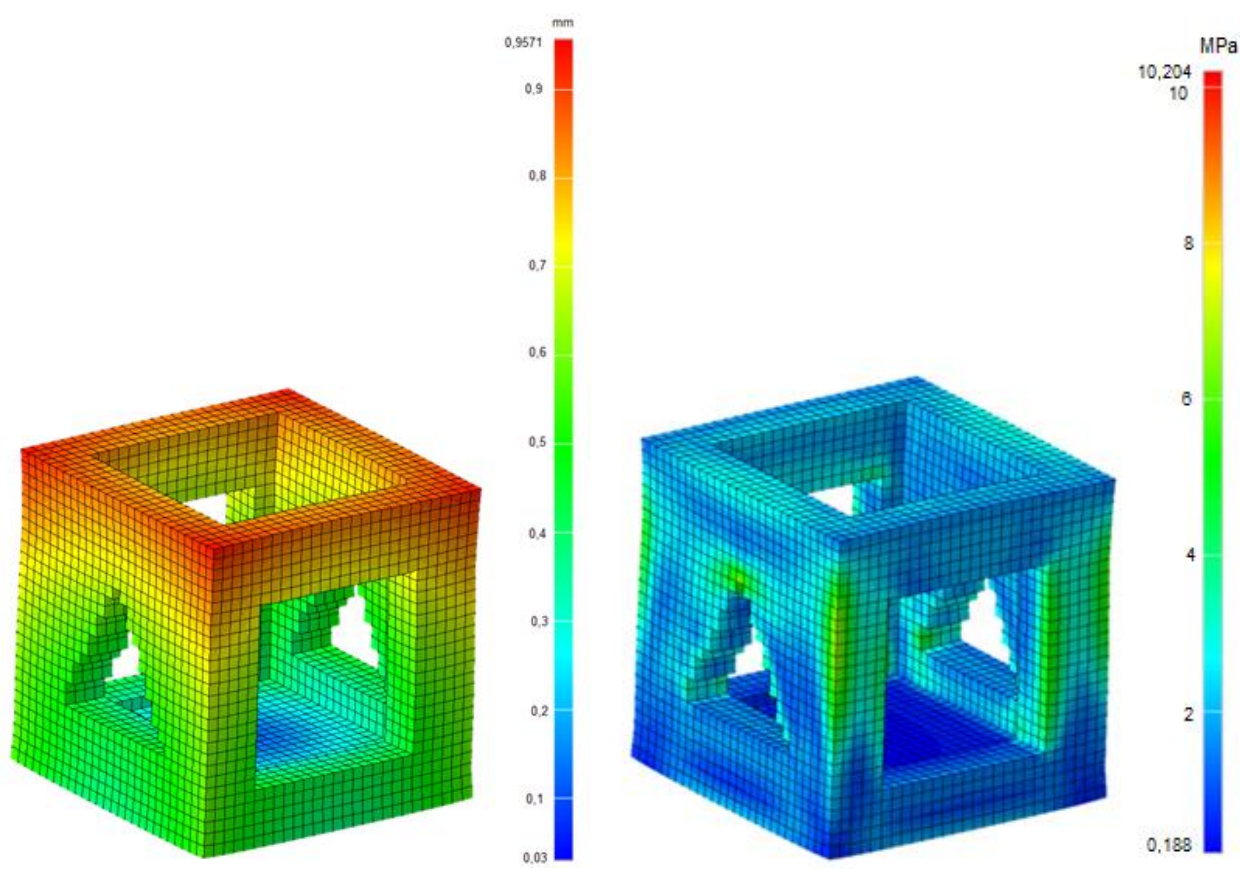

14. ábra. Tesztkocka vetemedési eredménye (bal) Tesztkocka feszültségei (jobb)

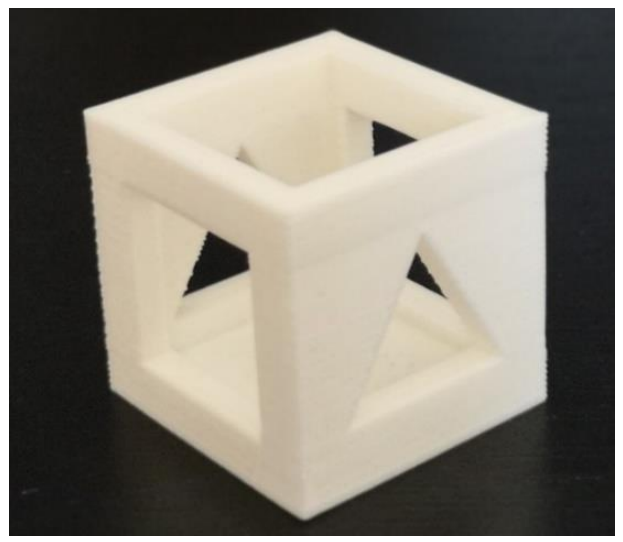

15. ábra. Nyomtatott ABS próbadarab

\section{1. Összegzés, következtetések}

A Digimat AM által számított eredmények jó egyezést mutatnak a valóságban kinyomtatott kocka vetemedésével (15. ábra). Az alsó szintekben bekövetkező változásokat karima hozzáadásával lehet csökkenteni, vagy megszüntetni, mivel azzal növelhető az alap felülete és jobban eloszlanak a terhelések. Az élekben fellépő deformáció mértéke csökkenthető, ha a nyitott részek alátámasztást kapnak, illetve, ha az egész nyomtató kap egy burkolatot, ahol közel állandó hőmérséklet tartható.

A kutatásomat folytatva, további anyagokat tesztelek, mechanikai vizsgálatokat végzek az anyagtulajdonságok és nyomtatási paraméterek vizsgálatára és további optimalizálására. 


\section{Irodalom}

[1] Tamás, P., Illés, B. (2016). Gyártórendszerek folyamatfejlesztési lehetőségei a negyedik ipari forradalomban. Müszaki Szemle, pp. 41-48.

[2] János, S.: A negyedik ipari forradalom - Industry 4.0. A Magyar Tudomány Napja a Délvidéken konferencia kiadványa. https://www.researchgate.net/publication/311257581_A_negyedik_ipari_forradalom_-_Industry_40

[3] Dilberoglu, U. M., Gharehpapagh, B., Yaman, U., Dolen, M. (2017). The role of additive manufacturing in the era of industry 4.0. Procedia Manufacturing, 11, pp. 545-554.

https://doi.org/10.1016/j.promfg.2017.07.148

[4] Haleem, A., Javaid, M. (2019). Additive manufacturing applications in industry 4.0: a review. Journal of Industrial Integration and Management, 4 (04), 1930001, https://doi.org/10.1142/S2424862219300011

[5] Tábi, T. (2015). Biopolimerek, biopolimerkompozitok. Előadás.

[6] Bodnár, I. (2016). Hulladékgazdálkodás IV., Müanyag és gumi hulladékok feldolgozása és hasznositása. Előadás.

[7] $20183 D$ Printer Filament Guide - All You Need to Know. https://all3dp.com/1/3d-printer-filament-types-3d-printing-3d-filament/ (Letöltés: 2020. 09. 28.)

[8] Hobbyking hivatalos oldala - ABS. https://hobbyking.com/en_us/pla-3d-printer-filament-white.html (Letöltés: 2020. 09. 28.)

[9] Simplify $3 D$ hivatalos oldala $-A B S$. https://www.simplify3d.com/support/materials-guide/abs/ (Letöltés: 2020. 09. 28.)

[10] Print Quality Troubleshooting Guide. https://www.simplify3d.com (Letöltés: 2020. 09. 28.)

[11] 2018 3D Printing Troubleshooting Guide: 41 Common Problems. https://all3dp.com/1/common-3d-printing-problems-troubleshooting-3d-printer-issues/ (Letöltés: 2020. 09. 28.)

[12] Simplify 3D, Rafts, Skirts and Brims. https://www.simplify3d.com/support/articles/rafts-skirts-and-brims/ (Letöltés: 2020. 09. 28.)

[13] Digimat 2017.1 Delivers the First Simulation Chain for Additive Manufacturing of Polymers. http://files.mscsoftware.com/cdn/farfuture/7gsRcns7onX101-F1j1p_ABCcy71xlDmMSEkyw N1Oy4/mtime:1489183476/sites/default/files/digimat-2017.1.pdf (Letöltés: 2020. 09. 28.)

[14] Digimat User Guide (Digimat AM segédlet).

[15] The 9 Different Types of 3D Printers, https://3dinsider.com/3d-printer-types/ (Letöltés: 2020. 09. 28.)

[16] Resinex hivatalos oldala, http://www.resinex.hu/poiimertipusok/ (Letöltés: 2020. 09. 28.)

[17] 3D printing Brim -When should you use it. https://all3dp.com/2/3d-printing-brim-when-should-you-use-it/ (Letöltés: 2020. 09. 28.)

[18] Brenken, B., Barocio, E., Favaloro, A., Kunc, V., Pipes, R. B. (2019). Development and validation of extrusion deposition additive manufacturing process simulations. Additive Manufacturing, 25, pp. 218-226., https://doi.org/10.1016/j.addma.2018.10.041

[19] D'Amico, A., Peterson, A. M. (2018). An adaptable FEA simulation of material extrusion additive manufacturing heat transfer in 3D. Additive Manufacturing, 21, pp. 422-430., https://doi.org/10.1016/j.addma.2018.02.021 